CV\% của 6 thông số ở 3 mức nồng đô đều nhỏ hơn $0,1 \%$. Như vậy, các ngưỡng giá trị mà nhóm nghiên cứu đưa ra là phù hợp và sẽ được sử dụng làm khoảng biến thiên của 6 thông số trong phương pháp tối ưu hoá các thành phần môi trường bảo quản mẫu.

\section{KẾT LUÂNN}

Nhóm nghiên cứu đã tiến hành khảo sát các giá trị ngưỡng thay đổi của 6 thông số thông qua các tài liệu y văn về ngưỡng bệnh lý, khoảng đo phân tích của thiết bị xét nghiệm để xác định các mức nồng độ cao, bình thường, thấp dùng trong pha chế mẫu. Kết quả thu được khoảng nồng độ cao của glucose là $9,50-24,00 \mathrm{mmol} / \mathrm{L}$, protein là 95 - $115 \mathrm{~g} / \mathrm{L}$, cholesterol là $6,20-9,00$ $\mathrm{mmol} / \mathrm{L}$, triglyceride là $2,70-9,50 \mathrm{mmol} / \mathrm{L}$, AST là $95-350 \mathrm{U} / \mathrm{L}$, ALT là $95-300 \mathrm{U} / \mathrm{L}$; khoảng nồng độ thấp của glucose là $2,49-3,90 \mathrm{mmol} / \mathrm{L}$, protein là $10-40 \mathrm{~g} / \mathrm{L}$, cholesterol là $2,50-3,70$ $\mathrm{mmol} / \mathrm{L}$, triglyceride là $0,20-1,00 \mathrm{mmol} / \mathrm{L}$, AST là 7 - 24 U/L, ALT là 7 - 24 U/L; khoảng nồng độ bình thường của glucose là $4,00-9,00 \mathrm{mmol} / \mathrm{L}$, protein là $45-90 \mathrm{~g} / \mathrm{L}$, cholesterol là $3,80-6,10$ $\mathrm{mmol} / \mathrm{L}$, triglyceride là $1,10-2,60 \mathrm{mmol} / \mathrm{L}$, AST là $25-94 \mathrm{U} / \mathrm{L}$, ALT là 25 - $94 \mathrm{U} / \mathrm{L}$. Để kiểm chứng kết quả thu được, 4 bộ mẫu được gửi đến 4 phòng xét nghiệm để phân tích. Kểt quả thu được là các dòng máy lựa chọn đều đọc được mẫu ở 3 mức nồng độ và kết quả giữa các dòng máy không có sự khác biệt nhiều.

KIẾN NGHİ. Sử dụng kết quả nghiên cứu để pha chế mẫu ngoại kiểm hóa sinh theo các tình trạng bệnh lý khác nhau, từ đó góp phần đảm bảo chất lượng xét nghiệm và nâng cao năng lực của các phòng xét nghiệm.

\section{TÀI LIÊU THAM KHẢO}

1. Bộ Y Tế (2014), Quyết định về việc ban hành tài liệu "Hướng dẫn quy trình kỹ thuật chuyên ngành Hóa sinh, Hà Nội.

2. Trân Hữu Tẩm và Lê Thị Thùy Như (2019), Nội kiểm tra chất lượng xét nghiệm, xuất bản lần 5 , Nhà xuất bản y hợ, TP.HCM.

3. Trân Hữu Tâm và cộng sự (2020), Ngoại kiểm tra chất lượng xét nghiệm, xuất bản lần 4, Nhà xuất bản y hoc, TP.HCM.

4. Solberg HË. Dybkaer R (1987), Approved recommendation on the theory of reference values, Part 6: Presentation of observed values related to reference values, International Federation of Clinical Chemistry (IFCC) - Clin Chim Acta, 170(S33-42).

5. Antony Barker Graham Jones (2008), Reference Intervals, Clin Biochem Rev, 29, 93-97. CraigJackson

\title{
ĐĂC ĐIỂM TỔN THƯƠNG Ở CÁC TRƯờNG HỢP CHẤN THƯƠNG MŨI, XOANG QUA GIÁM ĐİNH PHÁP Y THƯƠNG TÍCH
}

\section{TÓM TẮT.}

Mục tiêu: Mô tả đặc điểm tổn thương ở các trường hợp chấn thương mũi, xoang qua giám định pháp y thương tích. Đối tượng và phương pháp nghiên cứu: Nghiên cứu mố tả cắt ngang trên 98 trường hợp chấn thương mũi, xoang được giám định xác định tỷ lệ thương tích tại Viện Pháp y quốc gia từ tháng $01 / 2016$ đến tháng $10 / 2020$. Kết quả nghiên cứu: Gãy xương mũi chiếm tỷ lệ cao nhất $56,12 \%$, tổn thương xoang chiếm $35,71 \%$, seo phần mềm chiếm $25,51 \%$, vẹo vách ngăn mũi chiếm $14,29 \%$, kết hợp sẹo và tổn thương mũi xoang 4,08\%, tổn thương mũi, xoang với các tổn thương khác $21,43 \%$. Có $85,71 \%$ không có di chứng liên quan đến chức năng mũi, xoang chiếm tỷ lệ cao nhất, ảnh hưởng đến hạn chế mức độ thở là $3,06 \%$, viêm mũi xoang $6,12 \%$, di

*Viện Pháp y quốc gia

Chịu trách nhiệm chính: Nguyễn Đức Nhự

Email: nhund76@gmail.com

Ngày nhận bài: 21.6.2021

Ngày phản biên khoa họ: 20.8.2021

Ngày duyệt bài: 27.8.2021

\section{Nguyễn Đức Nhự, Trần Anh Tuấn}

chứng khác là 5,10\%. Kết quả phát hiện tổn thương trùng hợp với chẩn đoán của bệnh viển là $84,69 \%$, không truung hợp là $15,31 \%$. Vật gây thương tích do vật tày chiếm tỳ lệ cao nhất là $45,92 \%$, vật sắc, nhọn chiếm $13,27 \%$, hỏa khí $1,02 \%$, không rõ vật gây thương tích là $3,06 \%$, không yêu câuu giám định vật gây thương tích là $36,73 \%$.

Tư khóa: Chấn thương mũi, xoang, giám định pháp y thương tích.

\section{SUMMARY}

\section{CHARACTERISTICS OF INJURY IN CASES} OF NASAL AND SINUS TRAUMA THROUGH

\section{FORENSIC MEDICINE EXAMINATION}

Objectives: To describe the characteristics of injuries in cases of nasal and sinus trauma through forensic medicine examination. Subjects and methods: A cross-sectional descriptive study on 98 cases of nasal and sinus trauma assessed to determine the rate of injury at the National Institute of Forensic Medicine from January 2016 to October 2020. Research results: Nose fractures accounted for the highest rate of $56.12 \%$, sinus lesions accounted for $35.71 \%$, soft tissue scars accounted for $25.51 \%$, 
deviated nasal septum accounted for 14.29\%, combined scarring and nasal, sinus injury $4.08 \%$, nasal, sinus injury with other lesions $21.43 \%$. There were $85.71 \%$ no sequelae related to nasal function, sinus accounted for the highest percentage, affecting the breathing level was $3.06 \%$, sinusitis $6.12 \%$, other sequelae were $5.10 \%$. The result of finding lesions coincided with the hospital's diagnosis was $84.69 \%$, $15.31 \%$ did not coincide. Objects causing injuries due to blunt objects accounted for the highest rate was $45.92 \%$, sharp and pointed objects accounted for $13.27 \%$, firearms accounted for $1.02 \%$, unknown injuries were $3.06 \%$, not required assessment of injured objects was $36.73 \%$.

Key words: nasal and sinus trauma, forensic medicine examination.

\section{I. ĐĂT VẤN ĐỀ}

Trong chấn thương tai mũi họng, chấn thương mũi, xoang gặp nhiều nhất, chiếm tỷ lệ $78 \%$ [1]. Chấn thương gặp phổ biến trong tai mũi họng, có thể chấn thương đơn thuần hoặc phối hợp với chấn thương của các chuyên khoa khác và ảnh hưởng đến chức năng, thẩm mỹ, có thể ảnh hưởng đến tính mạng bệnh nhân. Trong giám định pháp $\mathrm{y}$, việc xác định tỷ lệ tổn thương cơ thể (TTCT) do chấn thương vùng mũi, xoang thường khá phức tap do có liên quan đến nhiều tổn thương như mũi, hêe thống các xoang vùng mặt hoặc tổn thương các vùng lân cận như cơ quan thị giác, răng hàm mặt, tai mũi họng, thậm chí có thể kèm theo chấn thương sọ não. Việc xác định di chứng chấn thương vùng mũi xoang đôi khi cũng rất khó khăn do phải chứng minh được các di chứng đó có phải là hậu quả của chấn thương gây ra hay không như veo vách ngăn mũi, ảnh hưởng đến chức năng thở, ngửi như thế nào hoặc đánh giá tình trạng viêm mũi, viêm xoang có phải xảy ra sau chẩn thương hay không? Bên cạnh đó, chấn thương mũi, xoang có nhiều nguyên nhân gây ra, trong đó phải kể đến nguyên nhân do tai nạn hay do bị đánh vào vùng mũi xoang gây ra. Chấn thương do vật gì tác động cũng là một trong những câu hỏi mà các GĐV thường phải trả lời chính xác để các cơ quan tiến hành tố tụng căn cứ để xử lý vụ án, vụ việc một cách chính xác, khách quan. Để giải quyết được những vấn đề khó khăn trên, các GĐV cần phải có kinh nghiệm, kết hợp với chỉ định cận lâm sàng đúng đắn và có thể phải tiến hành hội chẩn với các chuyên gia chuyên ngành tai mũi họng, chẩn đoán hình ảnh,... Do đó, chúng tôi nghiên cứu đề tài này nhằm mục tiêu: Mô tả đặc điểm tổn thương ở các trường hợp chấn thương mũi xoang qua giám định tỷ lệ TTCT.
II. ĐỐI TƯỢNG VÀ PHƯƠNG PHÁP NGHIÊN CỨU

2.1. Đối tượng nghiên cứu. Tổng số 98 trường hợp chấn thương mũi, xoang được giám định xác định tỷ lệ TTCT tại Viện Pháp y quốc gia (47 trường hợp) và Phân Viện tại TP. Hồ chí Minh (51 trường hợp) trong thời gian từ tháng 01 năm 2016 đến tháng 10 năm 2020.

\subsection{Phương pháp nghiên cứu} cứu.

Nghiên cứu cắt ngang mô tả: Hồi cứu và tiến

Tiêu chí lựa chọn: Các trường hợp được giám định tỷ lệ TTCT liên quan đến tổn thương mũi, xoang.

Tiêu chí loai trừ: Các trường hợp bênh lý vùng mũi xoang không liên quan đến chấn thương; Các trường hợp đang trong giai đoạn điều tra.

2.3. Xử lý thống kê số liêu: Phần mềm Excell 2013 để thống kê và tính tỷ lệ \%.

III. KẾT QUẢ NGHIÊN CỨU

Bảng 3.1. Đặc điểm di chứng chấn thương khi giám định

\begin{tabular}{|c|c|c|}
\hline $\begin{array}{c}\text { Phát hiện di chứng chấn } \\
\text { thương }\end{array}$ & $\begin{array}{c}\text { Số } \\
\text { lượng }\end{array}$ & $\begin{array}{c}\text { Tỷ lệ } \\
\text { \%o }\end{array}$ \\
\hline Sẹo phần mềm & $25 / 98$ & 25,51 \\
\hline Gãy xương mũi & $55 / 98$ & 56,12 \\
\hline Vẹo vách ngăn mũi & $14 / 98$ & 14,29 \\
\hline Tốn thương xoang & $35 / 98$ & 35,71 \\
\hline $\begin{array}{c}\text { Kết hợp sẹo và tốn thương } \\
\text { mũi xoang }\end{array}$ & $4 / 98$ & 4,08 \\
\hline $\begin{array}{c}\text { Kết hợp mũ̃i, xoang và các } \\
\text { tô̂n thương khác }\end{array}$ & $21 / 98$ & 21,43 \\
\hline
\end{tabular}

Nhận xét: Di chứng gãy xương mũi chiếm tỳ lệ cao nhất $56,12 \%$. Di chứng tổn thương xoang chiếm $35,71 \%$. Di chứng sẹo phần mềm $25,51 \%$, vẹo vách ngăn mũi $14,29 \%$, kết hợp sẹo và tổn thương mũi xoang $4,08 \%$, di chứng tổn thương mũi, xoang với các tồn thương khác $21,43 \%$.

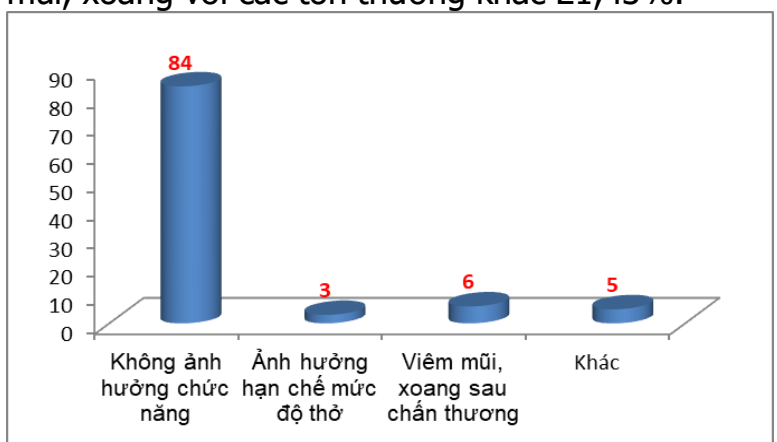

Biểu đồ 3.1. Phát hiện di chứng liên quan đến chức năng mũit, xoang

Nhận xét: Có $85,71 \%$ không có di chứng liên quan đến chức năng mũi, xoang chiếm tỷ lệ 
cao nhất, di chứng ảnh hưởng đến hạn chế mức độ thở là 3,06\% và viêm mũi xoang 6,12\%, di chứng khác là 5,10\%.

Bảng 3.2. Chỉ định cận lâm sàng khi giám dịnh

\begin{tabular}{|c|c|c|}
\hline Chỉ định cận lâm sàng & Số lượng & Tỷ lệ \% \\
\hline Xquang thường & $15 / 98$ & 15,31 \\
\hline CT Scanner & $87 / 98$ & 88,78 \\
\hline MRI & $15 / 98$ & 15,31 \\
\hline EEG & $31 / 98$ & 31,63 \\
\hline Siêu âm, nội soi & $2 / 98$ & 2,04 \\
\hline
\end{tabular}

Nhân xét: Chỉ định chụp CT scanner chiếm tỷ lệ cao nhất 88,78\%, EEG chiếm 31,63\%, Xquang và MRI đều chiếm 15,31\%, siêu âm, nội soi chỉ chiếm 2,04\%.

Bảng 3.3. Chi định khám chuyên khoa khi giám định

\begin{tabular}{|c|c|c|}
\hline $\begin{array}{c}\text { Chỉ định khám } \\
\text { chuyên khoa }\end{array}$ & Số lượng & Tỷ lệ $\%$ \\
\hline Răng hàm mặt & $6 / 98$ & 6,12 \\
\hline Tai Mũi Họng & $18 / 98$ & 18,37 \\
\hline Mắt & $10 / 98$ & 10,20 \\
\hline Thần kinh & $7 / 98$ & 7,14 \\
\hline
\end{tabular}

Nhận xét: Chỉ định khám chuyên khoa Tai mũi họng chiếm tỷ lệ cao nhất là $18,37 \%$, chuyên khoa mắt $10,20 \%$, chuyên khoa thân kinh $7,14 \%$ và chuyên khoa Răng hàm mặt $6,12 \%$.

Bảng 3.4. Đôi chiêu kết quả giám định và chân đoán của bệnh viện

\begin{tabular}{|c|c|c|}
\hline Kết quả & Số lượng & Tỷ lệ \% \\
\hline Trùng hợp & 83 & 84,69 \\
\hline Không trùng hợp & 15 & 15,31 \\
\hline Tống số & $\mathbf{9 8}$ & $\mathbf{1 0 0}$ \\
\hline
\end{tabular}

Nhận xét: Kết quả phát hiện tốn thương trùng hợp với chẩn đoán của bênh viện là $84,69 \%$, kết quả không trùng hợp với chẩn đoán của bệnh viện là 15,31\%.

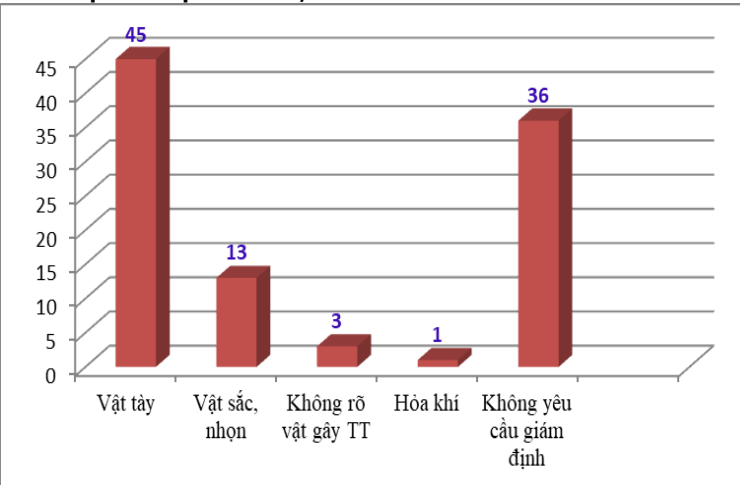

Biểu đồ 3.2. Phân loại theo vật gây thương tích

Nhận xét: Vật gây thương tích là vật tày chiếm tỷ lệ cao nhất là $45,92 \%$, vật sắc, nhọn chiếm $13,27 \%$, hỏa khí $1,02 \%$, không rõ vật gây thương tích là 3,06\%.

\section{BÀN LUÂNN}

4.1. Đặc điểm di chứng chấn thương khi giám định. Kết quả nghiên cứu cho thấy di chứng chấn thương vùng mũi, xoang khá đa dạng bao gồm: Sẹo phần mềm; gãy xương mũi; veo vách ngăn; gãy xương vùng xoang; kết hợp tổn thương mũi xoang và phối hợp các tổn thương khác. Trong đó, di chứng chấn thương gãy xương mũi chiếm tỷ lệ cao nhất $56,12 \%$. Di chứng tổn thương xoang chiếm $35,71 \%$. Di chứng sẹo phần mềm chiếm $25,51 \%$, vẹo vách ngăn mũ̃i chiếm $14,29 \%$, kết hợp sẹo và tổn thương mũi xoang $4,08 \%$, di chứng tổn thương mũi xoang với các tổn thương khác $21,43 \%$. Kết quả này cũng tương đối phù hợp với kết quả chẩn đoán lâm sàng khi điều trị tại bệnh viện cho thây tổn thương gãy xương mũi, xoang cũng chiếm tỷ lệ cao nhất so với tổn thương veoo vách ngăn mũi, tổn thương phần mềm và các tổn thương khác.

4.2. Phát hiện di chứng liên quan đến chức năng mũi, xoang. Trong khi giám định, ngoài việc chẩn đoán tổn thương chính thì các GĐV còn phải phát hiện xem có di chứng tổn thương có liên quan hay không để xác định tỷ lệ TTCT được chính xác. Kết quả nghiên cứu cho thấy, có $85,71 \%$ không có di chứng liên quan đến chức năng mũi, xoang chiếm tỷ lệ cao nhất, di chứng ảnh hưởng đến hạn chế mức độ thở là $3,06 \%$ và viêm mũi xoang $6,12 \%$, di chứng khác là $5,10 \%$. Kết quả này cũng hoàn toàn phù hợp, vì các trường hợp trong nghiên cứu này chúng tôi thấy nạn nhân bị chấn thương vùng mũi xoang, chủ yếu bị tổn thương xương mũi, xương vùng xoang đơn thuần. Do vậy, ít để lại các di chứng khác như ảnh hưởng đến chức nằng thở, ngửi cũng như di chứng viêm nhiễm... Ngoài ra, việc xác định di chứng ảnh hưởng đến chức năng thở và ngửi cũng không phải dể dàng, nhất là ở những cơ sở y tế tuyến dưới. Khi chẩn đoán có hạn chế thở và ngửi thì các GĐV còn phải xác định di chứng đó có liên quan đến hậu quả của chấn thương mũi xoang hay không để xếp tỷ lệ TCTT. Đây cũng là một trong những vấn đề khó khăn khi giám định.

4.3. Chỉ định cận lâm sàng khi giám định. Khi giám định, các GĐV sẽ căn cứ vào tổn thương vùng mũi, xoang và các tổn thương liên quan để chỉ định cận lâm sàng cho phù hợp. Trong đó, các GĐV sẽ chỉ định những cận lầm sàng tốt nhất, cần thiết để phát hiện tổn thương và các di chứng nếu có. Kết quả nghiên cứu cho thấy chỉ định chụp CT scanner chiếm tỷ lệ cao nhất là $88,78 \%$. Khi chỉ định cận lâm sàng, các 
GĐV cũng cần chỉ định CT scanner để còn đối chiếu kết quả tương ứng. Bên cạnh đó, các trường hợp chấn thương vùng mũi, xoang có liên quan đến chấn thương so não và tầng trên của hàm mặt nên chỉ định đo điện não (EEG) cũng chiếm tỳ lệ khá cao là 31,63\%. Một số chỉ định khác chiếm tỷ lệ ít hơn như chụp Xquang và MRI đều chiếm 15,31\%, siêu âm, nội soi chỉ chiếm 2,04\%.

4.4. Chỉ định khám chuyên khoa khi giám định. Kết quả nghiên cứu cho thấy: Chỉ định khám chuyên khoa Tai mũi họng chiếm tỷ lệ cao nhất là $18,37 \%$, khám chuyên khoa mắt $10,20 \%$, khám chuyên khoa thần kinh $7,14 \%$ và khám chuyên khoa Răng hàm mặt $6,12 \%$. Kết quả này chúng tôi thây phù hợp với thực tế vì chấn thương mũi chiếm tỷ lệ cao nhất, do vậy chỉ định khám chuyên khoa Tai mũi họng cũng chiếm tỷ lệ cao nhất. Mục đích chủ yểu là xác định các di chứng chấn thương vùng mũi có ảnh hưởng đến chức năng thở hoặc ngửi hay không để còn xác định tỷ lệ TTCT cho phù hợp. Tuy nhiên, hiện nay ở Việt Nam, việc đánh xác định ảnh hưởng chức năng ngửi của bệnh nhân liên quan đến chấn thương hay không là rất khó khăn và hầu hết các cơ sở chuyên khoa không đánh giá được. Chính vì vậy, Thông tư số 22/2019/TT-BYT ngày 28/8/2019 của Bộ Y tế hiện nay chỉ có mục ảnh hưởng đến chức năng thở mà chưa có tỳ lệ TTCT với di chứng chấn thương ảnh hưởng đến chức năng ngửi [2].

4.5. Đối chiếu kết quả giám định và chẩn đoán của bệnh viện. Kết quả đổi chiếu giữa giám định và chẩn đoán tại bệnh viện cho thấy: Kết quả phát hiện tổn thưởng trùng hợp với chẩn đoán của bệnh viện là $84,69 \%$, kết quả không trùng hợp với chẩn đoán của bệnh viện là $15,31 \%$. Như vậy, có một tỷ lệ khác nhau về chẩn đoán chấn thương ban đầu và khi giám định không trùng hợp nhau chiếm tỷ lệ khá cao. Theo chúng tôi có một số nguyên nhẩn cơ bản như sau: Một là, có những trường hợp bệnh nhân có tổn thương gẫy xương chính mũi hoăc tổn thương xoang nhưng bệnh viện không chẩn đoán được do kỹ thuật cận lâm sàng chưa tốt hoặc trình độ đọc kết quả và chẩn đoán của bác sĩ điều trị chưa đúng. Ví dụ gãy xương chính mũi, tổn thương các xoang... đã bị bỏ sót. Hai là, một số tổn thương ban đầu chụp thấy có gẫy xương nhưng khi giám định không còn phát hiện thây gãy xương. Ví dụ 02 trường hợp giám định khi chỉ định chụp CT Ścanner sọ não: không thây dấu hiệu tổn thương xương chính mũi. Tuy nhiên, khi hội chẩn đọc lại X-quang xương chính mũi chụp ngày 27/10/2018 tại Bệnh viện đa khoa tỉnh thấy mất liên tục đoạn $1 / 3$ xa xương chính mũi do gãy xương chính mũi di lệch ít. Ba là, có sự khác biệt về chẩn đoán tổn thương. Có trường hợp bệnh viện chẩn đoán là võ xương trán nhưng khi giám định thì chẩn đoán là võ xoang trán. Vì kết luận giám định cần phải chuẩn theo vị trí cụ thể của tổn thương để xếp tỷ lệ TTCT cho đúng khung tỷ lệ. Bốn là, có sự khác biệt về di chứng tổn thướng liên quan. Chẳng hạn, ban đâu bệnh viện có chẩn đoán là mất ngửi nhưng khi giám định ở tuyến trên thì chuyên khoa không thể xác định được mất ngửi... và ngược lại. Tổn thương ban đâu ở bệnh viện có thế mới nên ảnh hưởng đến chức nẳng thở nhưng khi tổn thương ổn định không còn di chứng hoặc khi điều trị ban đầu chưa ảnh hưởng đến thở nhưng di chứng chấn thương vẹo vách ngăn mũi về sau ảnh hưởng đến ngửi.

4.6. Phân loại theo vật gây thương tích. Kết quả nghiên cứu cho thấy: Vật gây thương tích do vật tày chiếm tỷ lệ cao nhất là $45,92 \%$, vật sắc, nhọn chiếm 13,27\%, hỏa khí 1,02\%, không rõ vật gây thương tích là 3,06\%. Có 36,73\% các trường hợp không yêu cầu giám định vật gây thương tích. Nguyên nhân chấn thương liên quan đến bạo lực, đả thương gây thương tích cho người khác chiếm tỷ lệ cao nhất $78,57 \%$, chủ yếu là liên quan đến vật tày, vật sắc, sắc nhọn. Trong nghiên cứu này, chúng tồi thây vật gây thương tích là vật tày khá đa dạng như: chủ yếu là đối tượng dùng tay, chân đánh vào vùng đầu mặt, dùng đá, gạch, thanh sắt, gậy, điếu cày, mũ bảo hiểm tác động vào vùng mặt, mũi xoang gây thương tích. Vật sắc, nhọn gầy thương tích như dao, kiếm, bồ cào, vv. Chỉ có 01 trường hợp vật gây thương tích là hỏa khí trong nghiên cứu này là do đạn bắn. Có 3,06\% trường hợp chúng tôi không xác định được vật gây thương tích cụ thể là vật gì do tổn thướng khá phức tạp hoặc không được mô tả kỹ tổn thương ban đầu, đến thời điểm hiện tại không rõ dấu vết. Kết quả này khác với kểt quả nghiên cứu của Nguyễn Hữu Khôi trên 129 trường hợp chấn thương gẫy xương mũi ở người lớn tại Bệnh viên Nhân dân Gia Định cho thấy trong năm nhóm nguyên nhân chấn thương mũi thì tai nạn giao thông đứng đầu với tỷ lệ $52 \%$, tiếp theo là do đả thương chiếm $33 \%$...[4]. Vì hai nhóm đối tượng nghiên cứu khác nhau, đối tượng điều trị ở bệnh viện chủ yếu liên quan đến tai nạn, còn đối tượng giám định chủ yếu liên quan đến bạo lực, đả thương.

\section{KẾT LUẬN}

- Gãy xương mũi chiếm tỷ lệ cao nhất $56,12 \%$, tổn thương xoang chiếm $35,71 \%$, sẹo 
phần mềm $25,51 \%$, veo vách ngăn mũi $14,29 \%$, kết hợp sẹo và tổn thương mũi xoang 4,08\%, di chứng tổn thương mũi, xoang với các tổn thương khác $21,43 \%$.

- Có 85,71\% không có di chứng liên quan đến chức năng mũi, xoang chiếm tỷ lệ cao nhất, di chứng ảnh hưởng đến hạn chế mức độ thở là $3,06 \%$ và viêm mũi xoang $6,12 \%$, di chứng khác là $5,10 \%$.

- Chỉ định chụp CTscanner chiếm tỷ lệ cao nhất $88,78 \%$, EEG chiếm $31,63 \%$, Xquang và MRI đều chiếm $15,31 \%$, siêu âm, nội soi $2,04 \%$. Chỉ định khám chuyên khoa Tai mũi họng chiếm tỷ lệ cao nhất là $18,37 \%$, chuyên khoa Mắt $10,20 \%$, chuyên khoa thần kinh $7,14 \%$ và chuyên khoa Răng hàm mặt $6,12 \%$.

- Kết quả phát hiên tổn thương trùng hợp với chẩn đoán của bệnh viện là $84,69 \%$, kết quả không trùng hợp với chẩn đoán của bệnh viện là $15,31 \%$.

- Vật gây thương tích do vật tày chiếm tỷ lệ cao nhất là 45,92\%, vật sắc, nhơn chiếm $13,27 \%$, hỏa khí $1,02 \%$, không rõ vật gây thương tích là $3,06 \%$. Có 36,73\% các trường hợp không yêu cầu giám định vật gây thương tích.

\section{TÀI LIÊU THAM KHẢO}

1. Đă̆ng Thanh (2012). Nghiên cứu đặc điểm dịch tể và lâm sàng chấn thương tai mũi hơng tai bếnh viện Trung ương Huế. Tạp chí Y dược học Quân sự, 153-160, số 2-2012.

2. Thông tư' số $\mathbf{2 0 / 2 0 1 4 / T T - ~ B Y T ~ n g a ̀ y ~} 12 / 6 / 2014$ của Bộ Y tế.

3. Thông tư số $22 / 2019 / T T-$ BYT ngày $28 / 8 / 2019$ của Bộ Y tế.

4. Nguyễn Hữu Khôi (2005). Nghiên cứu một số yếu tố dịch tễ của gãy xương chính mũi do chấn thương. Tạp chí Y học Thành phố Hồ Chí Minh. Tập 9, (1), 2005.

\section{THỰC TRẠNG BÊ̂NH VIÊM LỢI VÀ VÊ SINH RĂNG MIỆNG CỦA HỌC SINH LỚP 6 TRƯỜNG THCS CỔ BI, GIA LÂM, HÀ Nô̂I NĂM 2020}

Trần Thị Mỹ Hạnh ${ }^{1}$, Hoàng Hồng Xiêm ${ }^{1}$, Vũ Mạnh Tuấn ${ }^{1}$, Nguyễn Phú Thắng ${ }^{1}$, Đàm Văn Việt ${ }^{2}$, Phạm Thị Tuyết Nga ${ }^{1}$

\section{TÓM TẮT}

Mục tiêu: nhận xét thực trạng bệnh viêm lợi và vệ sinh rẳng miệng của học sinh lớp 6 trường THCS Cổ Bi, Gia Lâm, Hà Nội. Đối tượng: Học sinh lớp 6 trường THCS Cổ Bi, Gia Lâm, Hà Nội. Phương pháp nghiến cứu: mô tả cắt ngang. Kết quả: tî lể hoc sinh bị viêm lợi là 78,29\%. Tỉ lể học sinh viêm lợi nhe chiếm $31,01 \%$, viêm trung bình chiếm $29,46 \%$ và̀ viêm nặng chiếm $17,83 \%$. Tỉ lệ học sinh có xếp loại OHI-S rất tốt chiếm $0 \%$, tốt chiếm $41,09 \%$, trung bình chiếm $56,59 \%$ và kém chiếm $2,32 \%$. Kết luận: tỉ lệ học sinh bị viêm lợi còn cao, tình trạng vệ sinh răng miệng của học sinh ở mức trung bình. lớp 6.

Tư khóa: viêm lợi, vệ sinh răng miêng, học sinh

\section{SUMMARY}

THE SEVERITY OF GINGIVITIS AND ORAL HYGIENE PRACTICE AMONG 6 $^{\text {TH }}$ GRADERS

FROM CO BI SECONDARY SCHOOL, GIA LAM, HA NOI 2020

Objective: assess the severity of gingivitis and oral hygiene practice among $6^{\text {th }}$ graders from $\mathrm{Co} \mathrm{Bi}$,

\footnotetext{
1 Trường Đại học Y Hà Nọi

²Bênh viên Răng Hàm Măt Trung Uơng Hà Nôii

Chịu trách nhiệm chính: Trần Thị Mỹ Hạnh

Email: tranmyhanh@hmu.edu.vn

Ngày nhân bài: 22.6.2021

Ngày phản biên khoa hoc: 19.8.2021

Ngày duyệt bài: 26.8.2021
}

Gia Lam, Ha Noi. Subjects: $6^{\text {th }}$ graders from Co Bi, Gia Lam, Ha Noi. Method: cross sectional study. Results: the number of student with gingivitis accounts for $78,29 \%$. The number of students with mild, moderate and severe gingivitis is $31,01 \%$, $29,46 \%$ and $17,83 \%$, respectively. When it comes to simplified oral hygiene index (OHI-S), student with excellent, good, fair and poor score account for $0 \%$, $41,09 \%, 56,59 \%$ and $2,32 \%$. Conclusion: the presence of gingivitis among students is at high incidence and oral hygiene is still and at fair level.

Keyword: gingivitis, oral hygiene, $6^{\text {th }}$ graders.

\section{I. Đă̆T VẤN ĐỀ}

Sâu răng, viêm lợi là những bệnh lý răng miệng phổ biến ở trẻ em. Tại Việt Nam, tỉ lệ học sinh mắc bệnh răng miệng khoảng $85 \%{ }^{1}$. Các bệnh răng miệng này không những ảnh hưởng tới chức năng ăn nhai, thẩm mỹ mà còn gây những biến chứng tại chỗ và toàn thân. Việc hiểu biết và thực hành chăm sóc răng miệng đúng cách, hiệu quả đóng vai trò quyết định trong dự phòng các bênh răng miệng. Ngày nay, vấn đề chăm sóc răng miệng ở trẻ em đã được quan tâm nhiều, chương trình nha học đường đã được triển khai rộng khắp 58/63 tỉnh thành và đạt được những thành tựu đáng kểe tuy nhiên tỷ lệ trẻ em bị mắc các bệnh lý răng miệng vẫn còn cao. Theo kết quả điều tra sức khỏe răng miệng toàn quốc năm 2001, tỉ lệ viêm lợi ở trẻ em 12 